\section{Stress Distribution in Co-Cr Implant Frameworks after Laser or TIG Welding}

Gabriela Cassaro de Castro ${ }^{1}$, Cleudmar Amaral de Araújo², Marcelo Ferraz Mesquita', Rafael Leonardo Xediek Consani', Mauro Antônio de Arruda Nóbilo ${ }^{1}$
'Department of Prosthodontics and Periodontics, Piracicaba Dental School, UNICAMP - University of Campinas, Piracicaba, SP, Brazil ${ }^{2}$ Laboratory of Mechanical Projects, UFU - Federal University of Uberlândia, School of Mechanical Engineering, Uberlândia, MG, Brazil

Correspondence: Profa. Gabriela Cassaro de Castro, Avenida Desembargador Santos Neves, 389/203, Praia do Canto 29055271 Vitória, ES, Brasil. e-mail:

\begin{abstract}
Lack of passivity has been associated with biomechanical problems in implant-supported prosthesis. The aim of this study was to evaluate the passivity of three techniques to fabricate an implant framework from a Co-Cr alloy by photoelasticity. The model was obtained from a steel die simulating an edentulous mandible with 4 external hexagon analog implants with a standard platform. On this model, five frameworks were fabricated for each group: a monoblock framework (control), laser and TIG welding frameworks. The photoelastic model was made from a flexible epoxy resin. On the photoelastic analysis, the frameworks were bolted onto the model for the verification of maximum shear stress at 34 selected points around the implants and 5 points in the middle of the model. The stresses were compared all over the photoelastic model, between the right, left, and center regions and between the cervical and apical regions. The values were subjected to twoway ANOVA, and Tukey's test $(\alpha=0.05)$. There was no significant difference among the groups and studied areas $(p>0.05)$. It was concluded that the stresses generated around the implants were similar for all techniques.
\end{abstract}

cassarodecastro@gmail.com

Key Words: biomechanics, photoelasticity, dental implants, stress analysis.

\section{Introduction}

Lack of passivity in the infrastructure and prosthetic dental implants has been associated with biomechanical problems such as screw loosening (1-7). Due to the rigid connection between implant and bone, all strength will be transmitted directly from the prosthesis to the alveolar bone (6-8). When the prosthesis does not rely passively on implants, compression forces and torques are applied to the bone-implant-prosthesis system, which could cause fracture of the prosthetic piece or even the screw in the implant (9). Although the amount of force able to generate disorders has not been established, it is known that, if the stresses exceed the capacity of the bone to withstand or dissipate them, it may enhance bone resorption or compromise the osseointegration (2,3,11-13).

The passive prosthesis design is challenging because clinical and laboratory procedures related to the manufacturing of Branemark's protocol prosthesis is difficult since distortions might occur at all stages $(2,8,10,13-15)$. Considering the need to increase the longevity of prostheses, several authors have suggested the use of a laser welding procedure for the correction of discrepancies present in metal monoblock frameworks $(1,4,10,16,17)$.

The use of tungsten inert gas (TIG) welding has been associated with flexural strength values greater than the values of laser welding for different alloys $(18,19)$. This is a new welding technique for dentistry, but has been largely used in engineering. The welding joint occurs by an electric arc between the nonconsumable tungsten electrode and the metal alloy pieces, protected by an inert gas atmosphere (10).

Given the possibility of using TIG welding for the fabrication of implant frameworks, an evaluation is proposed of three different processes of manufacturing metal frameworks from a chromium-cobalt ( $\mathrm{Co}-\mathrm{Cr}$ ) alloy for four implants: laser welding, TIG welding and monoblock. The evaluation was based on a photoelastic analysis of the stresses generated around the implants after screw tightening, throughout the photoelastic model in the right and left segments and in the center, along with a comparison of the tensions in the cervical and apical thirds.

\section{Material and Methods}

In a metallic circular stainless steel matrix $(90 \times 20 \times 10$ $\mathrm{mm}$ ), simulating an edentulous jaw, implants were inserted into regular platform and external hexagon analogs. The mesial analogues were positioned $10 \mathrm{~mm}$ away from the center of the matrix on each side, and the distal analogues were positioned at a distance of $10 \mathrm{~mm}$ from their respective mesial analogues. From this matrix, the working model and the photoelastic model were obtained by transfer impression with square components joined together with a metal rod and chemically activated acrylic resin (Pattern Resin LS; GC America Inc., Alsip, IL, USA) and silicon duplication (Silibor; Clássico Produtos Odontológicos Ltda., São Paulo, SP, Brazil).

For the fabrication of casting patterns for the 
monoblock, the frameworks and metal rods of the welded framework, prefabricated titanium alloy metal rods were duplicated in chemically activated resin (Pattern Resin LS, GC America Inc.) using silicone duplication (ZetaLabor Zhermack; Labordental, São Paulo, SP, Brazil), metal flasks, and UCLA calcinables (Signovinces, São Paulo, SP, Brazil).

The waxed monoblock frameworks, metal rods, and UCLA calcinables were fixed to the bases, forming a melting pot and were included coated (Castorit Super C; Dentaurum, Pforzheim, Germany). Casting was done using a Discovery Plasma casting machine (EDG Equipamentos e Controles Ltda., São Carlos, SP, Brazil) set for a Co-Cr alloy (2001 Remanium; Dentaurum, Pforzheim, Germany), with the following composition: Co: $63 \%$, Cr: 23\%, Mo: 7\%, W: 4.3\%. After cooling, the structures were deflasked and finished by blasting with aluminum oxide with a grain size of $100 \mu \mathrm{m}$ and a pressure of $4.5 \mathrm{~kg} / \mathrm{cm}^{2}$.

$\mathrm{Nd}$ :YAG laser welding was performed on a desktop laser machine (Dentaurum, Pforzheim, Germany) set at $365 \mathrm{~V}$, a $9.0 \mathrm{~ms}$ pulse and focus frequency equal to zero. The joining of the metal rod end UCLA calcinables with welding points was guided by a silicone matrix used for waxing of the monoblock structure to standardize the $\Xi$ position of the welded bars. Welding was performed at diametrically opposed points on the bar-abutment or the buccal-lingual superior-inferior interface until the entire diameter of the bar received welding points to minimize distortion (5). Alternate segments were also welded.

TIG welding was performed on a Plasma Micromelt Welding Machine (EDG, São Carlos, SP, Brazil) with a depth of 3 and 10 ms pulse. For the welding procedures, the alloy pieces were placed on the welding guide and an earth clamp was attached to the work piece. In an argon-gas environment, the tungsten electrode was located 3-6 mm from the work piece without letting the tungsten touch the metal alloy to avoid contamination. The welding current control was done by a foot pedal. Likewise for the laser welding, TIG welding was performed following the silicone matrix with diametrically opposed points and alternating segments. After all casting procedures and welding structures, 5 frameworks were obtained for each technique.

To proceed with the photoelastic analysis, a photoelastic model made from flexible epoxy resin system (GIII; Polipox Industria e Comércio Ltda, São Paulo, SP, Brasil) and with external hex implants with regular platform and $13 \mathrm{~mm}$ length (Signovinces, São Paulo, SP, Brazil). Two indexes with known dimensions were bonded to the photoelastic model, dividing the model into three regions to be evaluated: a first index that allowed the demarcation of the right and left regions $(13.0 \times 23.0 \mathrm{~mm}$ on each side) and another index referring to the central region $(13.0 \times 33.0 \mathrm{~mm})$.

The photoelastic model was positioned in a circular polariscope (Mechanical Laboratory Projects, Federal University of Uberlandia, Uberlândia, MG, Brazil) with the index for the lateral analysis, standing with the left face parallel to the polariscope filters. The framework was then bolted to the model, with initial tightening of $10 \mathrm{Ncm}$, followed by $20 \mathrm{Ncm}$, alternating the screws of the implants. Photographs (Canon EOS Rebel XS Digital SLR with Canon EF Macro USM autofocus $100 \mathrm{~mm} / 2.8$ telephoto lens - Canon Inc. Lake Success, NY, USA) were standardized for analysis of the stresses after the final tightening of the screws. After registering the tensions of each structure on the left side, the model was repositioned for the ascertainment of the right side, and then the index was changed and the tensions in the center obtained. The images were processed in a program image editor (Adobe Photoshop; Adobe Systems Incorporated, San Jose, CA, USA), trimmed to retain only the region contained in the index (Fig. 1). The photoelastic image analysis was performed using the Fringes software (Mechanical Laboratory Projects of Federal University of Uberlândia).

For quantitative photoelastic analysis, the Fringes software was applied to determine the maximum shear stress from the fractional number of fringe orders at the chosen points. This software compared RGB colors to known
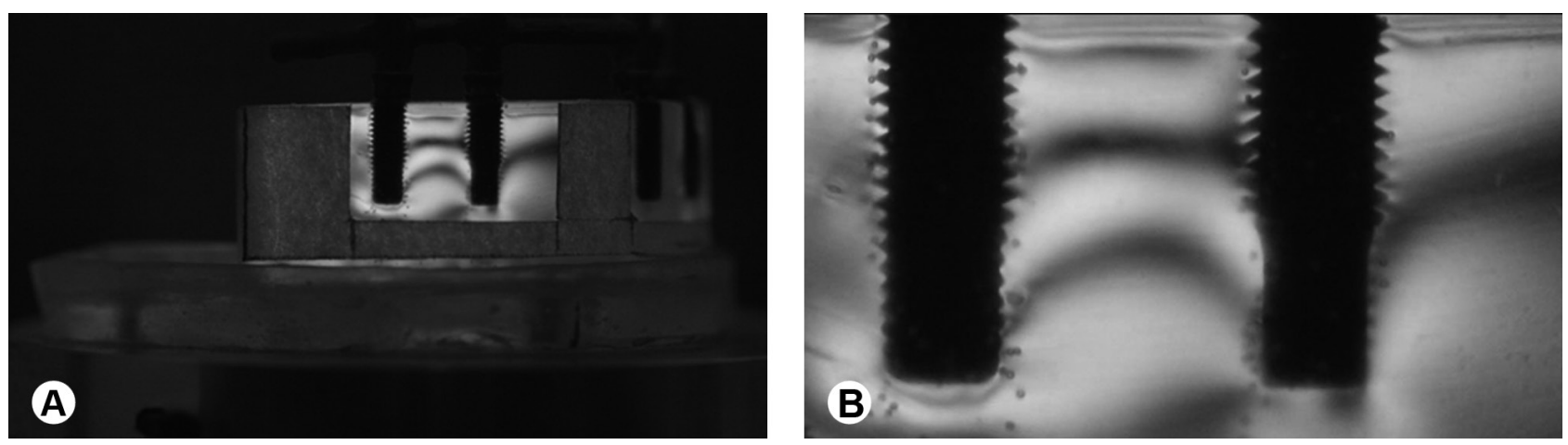

Figure 1. Photoelastic images before (A) and after (B) trimming to retain only the region contained in the index for the photoelastic analysis. 
fringe orders. The photoelastic material fringe pattern was determined from the optical constant of the photoelastic material, the Tardy compensation method, and application of the optical-tension law $(3,20,21)$.

For the left- and right-side photoelastic images, 17 points were analyzed on each side, arranged around the implant; and for the images relating to the center region of the model were chosen 5 points in the middle portion of the model. Thirty-nine were measured for each specimen, numbered 1 to 39 from left to right (Fig. 2). The results were tabulated and separated according to the desired comparison. Points 1-39 were used to verify the tensions around the photoelastic model. To compare the regions, the points were arranged as 1-17 on the left side, 18-22 in the center, and 23-39 on the right side. Further, a comparison between the cervical and apical points was done.

The maximum shear stress was obtained from predetermined points and the results were tabulated and statistically analyzed (SAS version 9.1; The SAS Institute, Cary, NC, USA). To compare the shear stress results, data were subjected to two-way ANOVA and Tukey's test with a significance level of $5 \%$.

\section{Results}

The results were tabulated (Table 1) to compare the stresses across the photoelastic model and on each side,

Table 1. Shear stress (kgf) means and standard deviations according to the framework fabrication technique and analyzed region (central, left and right)

\begin{tabular}{lccc}
\hline \multirow{2}{*}{ Region } & \multicolumn{3}{c}{ Technique } \\
\cline { 2 - 4 } & Monoblock & TIG & Laser \\
\hline Center & $20.49(12.58) \mathrm{Aa}$ & $25.28(23.87) \mathrm{Aa}$ & $23.31(18.67) \mathrm{Aa}$ \\
Left & $23.8(6.55) \mathrm{Aa}$ & $15.5(9.43) \mathrm{Aa}$ & $18.12(4.67) \mathrm{Aa}$ \\
Right & $18.90(7.70) \mathrm{Aa}$ & $18.72(1.61) \mathrm{Aa}$ & $15.34(5.09) \mathrm{Aa}$ \\
\hline
\end{tabular}

Different lowercase letters in columns and uppercase letters in rows indicate statistically significant difference (Tukey's test, $p>0.05$ ). showing no significant differences. It is important to report that, during the photoelastic analysis, two TIG welded frames were lost due to fracture of the joint of the metal bars with the abutment at different moments of analysis, so the values of the shear stress of these structures were analyzed for just a few points.

Table 1 shows the mean shear stress at each point for each technique for manufacturing the framework. In a numerical analysis of the results of the overall averages for each technique, the monoblock group had the highest average maximum shear stress, and the lowest was found in a laser welded framework. Statistically, there was no difference among the groups.

An analysis regarding deformation occurring on each side of the structures was also performed to better understand the behavior of the tensions. The points were separated into left (points 1-17), center (points 18-22), and right side (points 23-39) and showed no difference in the stresses among these regions ( $p>0.05$ ).

Maximum shear stress mean values from cervical points for each technique were: 15.72 (5.32) kfg for monoblock, 19.05 (8.43) kgf for TIG welding and 26.03 (7.39) kgf for laser welding ( $p>0.05)$. And the mean values from apical points for each technique were: 16.44 (6.99) $\mathrm{kgf}$ for monoblock, 16.44 (6.99) $\mathrm{kgf}$ for TIG welding and 17.65 (6.92) for laser welding. A comparison of the average between points located in the apical and the cervical regions showed no significant difference in the stresses in these regions ( $p>0.05)$.

\section{Discussion}

This study evaluated the stress distribution around implants after screw frameworks were fabricated by laser welding, TIG and monoblock structures. Analytical methods (such as finite element analysys) and experimental methods (such as extensometry and photoelasticity) can be applied in the evaluation of the resulting tensions. In templates with complex designs and loading, the use of analytical methods may be difficult or even impossible to run $(3,21)$.

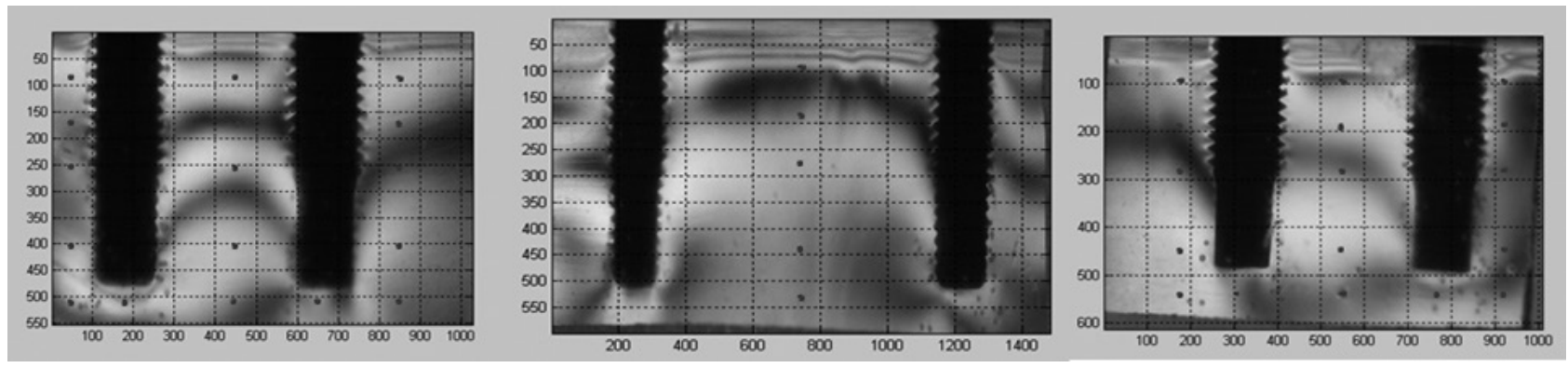

Figure 2. The 39 points analyzed on the photoelastic images in Fringes software: 17 points on the left side, 5 points on the center, and 17 points on the right side. The points are numbered 1 to 39 from left to right in each specimen. 
The extensometry, although providing quantitatively comparable stress values, collected data only on the surface areas where sensors were attached and the receivers were temperature-sensitive (6). The photoelasticity technique allows the analysis of tension across a photoelastic model, indicating the location of stress concentration, and is suitable for complex systems and loads $(3,16)$. A limitation of this technique is the reproducibility of the physical characteristics of peri-implant tissues since the model has photoelastic homogeneous and isotropic properties, while the bone has variations in the tensile modulus according to the region $(6,12,22)$.

In this study, the tensions were measured after bolting the framework to the abutments for the comparison of the deformation that occurred during the manufacturing process. A similar study demonstrated that the screwing of non-passive frameworks generated strains sensitive in photoelasticity (1). In the present study a quantitative verification of the tensions present in previously established points for the photoelastic model was performed, in a similar way reported in other investigations $(3,5,20)$.

Kim et al. (21) applied the photoelastic method only in a qualitative way, by fringe order. However, in the established for the calculation. The results of the stress analysis at all points of the photoelastic model showed tensions in all structures, without significant differences among the manufacture methods.

The similarity between the solders and the monoblock group in terms of tension may be due to the strict control of procedures for casting, and the equivalence can be associated with the large number of welding spots used in this study. The results of this study differ from those of various authors who reported the improvement of passivity when performing welding spots $(1,4,5,11,13,16)$. In such cases, few welding spots were used, limiting the distortion generated by the welding procedure.

The option of making structures by joining the metal bars to prosthetic abutments by welding was made because it is a widely used technique in implants under immediate load owing to its low cost and speed of manufacture. Furthermore, the application of various solder points allowed the evaluation of the effect of the welds relative to tensions in border situations.

It is likely that the extreme sensitivity of the TIG welding technique and external factors, such as operator experience, may have affected the evaluated welds. Still, Barbi et al. (10) reported that TIG welding presented smaller and fewer gap values than laser welding. Nevertheless, in these studies, a TIG welding group was used as a fill material, different from the laser welding group, and laser welding was accomplished without the use of argon shielding (10) and this might have caused the difference in the outcomes.

The similarity observed in the distribution of tensions between the right, left, and center regions may reflect the way of tightening the screw, which was carried out alternately between the central and distal implants and printing a first torque of $10 \mathrm{Ncm}$, followed by a torque of $20 \mathrm{Ncm}$. Furthermore, materials with a high modulus of elasticity, such as $\mathrm{Co}-\mathrm{Cr}$ alloys, promote distribution of stresses and can reduce the risk of possible fatigue fractures and related components of the overhead $(9,16,23)$.

The present study showed similarities between the tensions in the cervical and apical regions, unlike studies that reported higher stress concentration in the cervical region of implants $(14,16,17,22)$. This discrepancy may be due to factors related to the limitation of the experimental model. Similar tension distribution pattern has been reported by Begg et al. (12) in a photoelastic analysis of structures supported by four implants. The elastic behavior of the photoelastic resin differs from the peri-implant bone, which presents in the cervical region cortical bone with a higher modulus of elasticity, distributing and concentrating the stress $(12,17)$.

Although the amount of tension that the bone is able to withstand was not established, there is an agreement that a carefully planned and properly manufactured prosthesis is essential to prevent excessive sealing of the prosthetic components and the surrounding bone (8). Duyck et al. (24) observed crater-form bone defects around implants with maladaptive prostheses after dynamic loading. In a literature review on the risk factors that affect treatment with dental implants performed by Salvi and Brägger (25), it was observed that none of the studied factors, such as occlusal load, non-axial forces and stress biomechanics seemed to affect the implant and adjacent bone. However, the authors emphasized that the limitations of the reviewed studies may converge to yield a false negative. Abdou et al. (6) reported that the clinical determination of the passivity of implant structures can be affected by the angle of vision of the operator and his experience, even the location of the slit, stiffness of the structure, and number and distribution of implants. This emphasizes the importance of employing production techniques that result in precise frameworks, reducing the possibility of induced tensions to the prosthesis-implant-bone system $(6,15)$.

The clinical and laboratory variability that is intrinsic to the rehabilitation treatment can lead to distortions, which affect the passivity of the prosthetic piece (2). The adaptation is influenced by laboratory processes and 
welding procedures, which seem to favor passive structures. The selection of the method to build the implant framework will depend on operator experience, the alloy used and cost. Varying the fabrication technique and welding bar, it is important to know, from the biomechanical standpoint, the stress distribution pattern and intensity (23) and the mechanical strength for clinical application of the best materials and available techniques. In the present study, the tensions were evaluated by photoelasticity. The application of other experimental and analytical methodologies was aimed at a better understanding of the biomechanical behavior of both the peri-implant structures and the prosthetic components.

Within the limitations of the study design and considering the obtained results, it may be concluded that: 1 . There was no difference among the techniques regarding the peri-implant tensions; and 2. The pattern of stress distribution around the implants was similar in all analyzed regions.

\section{Resumo}

A falta de passividade tem sido associada a problemas biomecânicos em próteses implantossuportadas. A proposta deste estudo foi avaliar, por meio da fotoelasticidade, a influência de três diferentes de fabricação de infraestrutura em liga de $\mathrm{Co}-\mathrm{Cr}$ na passividade destas. $\mathrm{O}$ modelo foi obtido a partir de uma matriz de aço simulando uma mandibula edêntula com 4 análogos de implantes de hexágono externo com plataforma padrão. Neste modelo, foram confeccionados cinco amostras para cada grupo: infraestruturas em monobloco, infraestruturas soldadas a laser e soldadas a TIG. 0 modelo fotoelástico foi feito com uma resina epóxi flexivel (GIII, Polipox Industria e Comercio Ltda.). Na análise fotoelástica, as infraestruturas foram aparafusadas no modelo para a verificação da tensão de cisalhante máxima em 34 pontos selecionados ao redor dos implantes e 5 pontos na região média do modelo. Foram comparadas as tensões em todo o modelo fotoelástico, entre as regiões direita, esquerda e centro e também entre as regiões cervical e apical. Os valores foram submetidos à análise de variância a dois critérios, seguido pelo teste de Tukey $(\alpha=0,05)$. Os resultados não mostraram diferença significativa entre as tensões presentes nos grupos e nas áreas estudadas. Conclui-se que as tensões geradas ao redor dos implantes foram semelhantes entre as diferentes técnicas de confecção e entre todas as regiões analisadas.

\section{Acknowledgements}

This research was supported by grant 08/05123-5 from The São Paulo State Research Foundation (FAPESP).

\section{References}

1. Waskewicz GA, Ostrowki JS, Parks VJ. Photoelastic analysis of stress distribution transmitted from a fixed prosthesis attached to osseointegrated implants. Int J Oral Maxillofac Implants 1994;9:405411.

2. Naconecy MM, Teixeira ER, Shinkai RS, Frasca LC, Cervieri A. Evaluation of the accuracy of 3 transfer techniques for implant-supported prostheses with multiple abutments. Int J Oral Maxillofac Implants 2004;19:192-198.

3. Barbosa GAS, Simamoto-Júnior PC, Fernandes-Neto AJ, Mattos MGC, Neves FD. Prosthetic laboratory influence on the vertical misfit at the implant/UCLA abutment interface. Braz Dent J. 2007;18:139-143

4. Souza AS, De Arruda Nóbilo MA, Henriques GEP, Mesquita MF. Passive fit of frameworks in titanium and palladium-silver alloy submitted the laser welding. J Oral Rehab 2008;35:123-127.

5. Cariello MP, Nóbilo MAA, Henriques GEP, Mesquita MF, Consani RLX, Lira AF. Implant-supported titanium framework: photoelastic analysis before and after spark erosion procedure. Braz J Oral Sci 2010;9:48-53.

6. Abduo J, Bennani V, Waddell N, Lyons K, Swain M. Assessing the fit of implant fixed prostheses: a critical review. Int J Oral Maxillofac Implants 2010;25:506-515.

7. Byrne G. Soldering in prosthodontics - an overview, part 1. J Prosthodont 2011;20:233-243.

8. Sahin S, Çehreli MC. The significance of passive framework fit in implant prosthodontics: current status. Implant Dent 2001;10:85-92.

9. Rubo JH, Souza EAC. Finite element analysis of stress in bone adjacent to dental implants. J Oral Implantol 2008;34;248-255.

10. Barbi FCL, Camarini ET, Silva RS, Endo EH, Pareira JR. Comparative analysis of different joining techniques to improve the passive fit of Cobalt-Chromium superstructures. J Prosthet Dent 2012;108:377-385.

11. Tiossi R, Rodrigues RC, Mattos MGC, Ribeiro RF. Comparative analysis of the 3-unit implant-supported frameworks cast in nickel-chromium and cobalt-chromium alloys and commercially pure titanium after casting, laser welding, and simulate porcelain firings. Int J Prosthodont 2008;21:121-123.

12. Begg T, Geerts GAVM, Gryzagoridis J. Stress patterns around distal angled implants in the all-on-four concept configuration. Int J Oral Maxillofac Implants 2009;24:663-671.

13. Aguiar-Júnior FA, Tiossi R, Rodrigues RCS, Mattos MGC, Ribeiro RF. An alternative section method for casting and posterior laser welding of metallic frameworks for an implant-supported prosthesis. J Prosthodont 2009;18:230-234.

14. Gomes EA, Assunção WG, Tabata LF, Barão VAR, Delbem JA, Souza EAC. Effect of passive fit absence in the prosthesis/implant/retaining screw system: a two-dimensional finite element analysis. J Craniofac Surg 2009;20:2000-2006

15. Sierraalta M, Vivas JL, Pazzoog ME, Wang RF. Precision of fit titanium and cast implant frameworks using a new matching formula. Int J Dent 2012;2012:374315

16. Guichet DL, Caputo $A A$, Choi $H$, Sorensen JA. Passivity of fit and marginal opening in screw- or cement-retained implant fixed partial denture designs. Int J Oral Maxillofac Implants 2000;15:239-246.

17. Markarian RA, Ueda C, Sendyk CL, Laganá DC, Souza RM. Stress distribution after installation of fixed framework with marginal gaps over angled and parallel implants. J Prosthodont 2007;16:117-122.

18. Hart CN, Wilson PR. Evaluation of welded titanium joints used with cantilevered implant-supported prostheses. J Prosthet Dent 2006;96:25-32.

19. Rocha $\mathrm{R}$, Pinheiro ALB, Villa Verde $A B$. Flexural strength of pure $\mathrm{Ti}, \mathrm{Ni}-\mathrm{Cr}$ and $\mathrm{Co}-\mathrm{Cr}$ alloys submitted to Nd:YAG Laser or TIG welding. Braz Dent J 2006;17:20-23.

20. Bernardes $S R$, Araújo $C A$, Fernandes Neto AJ, Simamoto Júnior $P$, Neves FD. Photoelastic analysis of stress patterns from different implantabutment interfaces. Int J Oral Maxillofac Implants 2009;24:781-789.

21. Kim KS, Kim YL, Bae JM, Cho HW. Biomechanical comparison of axial and tilted implants for mandibular full-arch fixed prostheses. Int J Oral Maxillofac Implants 2011;26:976-984.

22. White SN, Caputo AA, Anderkvist T. Effect of cantilever length on the stress tracker by implant-supported prosthesis. J Prosthet Dent 1994;71:493-499.

23. Ogawa Dhaliwal S, Naert I, Mine A, Kronstrom M, Sasaki K, et al.. Impact of implant number, distribution and prosthesis material on loading on implants supporting fixed prostheses. J Oral Rehabil 2010;37:525-531.

24. Duyck J, Van Oosterwyck H, Vander Sloten J, De Cooman M, Puers R, Naert I. Magnitude and distribution of occlusal forces on oral implants supporting fixed prostheses: an in vivo study. Clin Oral Implant Res 2000;5:465-475.

25. Salvi GE, Brägger U. Mechanical and technical risks in implant therapy. Int J Oral Maxillofac Implants 2009;24:69-85.

Received November 16, 2012 Accepted February 20, 2013 